\title{
Forms of Cooperative Learning in Language Teaching in Slovenian Language Classes at the Primary School Level
}

\section{Alenka Rot Vrhovec ${ }^{1}$}

$\approx$ In the Slovenian language syllabus, teachers are recommended to provide a greater share of group work during class. During types of learning such as cooperative learning in smaller groups or pairs, students actively develop communicative competence. The present article presents a survey that attempted to determine whether teachers from the first to the fifth grade execute cooperative learning in language classes. The purpose of the article is to raise teachers' awareness and encourage them to design and execute cooperative learning more frequently.

Keywords: primary school, Slovenian, language classes, teaching methods, cooperative learning 


\section{Introduction}

Until 1970, cooperative learning was relatively unknown and, as such, was rarely adopted in practice, although "small-group learning has been used since the beginning of human existence" (Johnson \& Johnson, 2009a, p. 365). Instead, the recommended practice was the individualistic approach, which sought to allow individuals "to go through the curriculum at their own pace independent of classmates' rates of learning" (Johnson \& Johnson, 2009a, p. 365). The method of cooperative learning began to be applied on a larger scale after 1980, once individualistic learning had been challenged by social scientists who pointed out the role of peer interaction and its effects on socialisation (Johnson \& Johnson, 2009a). In addition, the results of research into traditional teaching methods ushered in the trend of the modern era in which the transmission mode of teaching, which forced the pupil to passively accept and absorb facts (1915, in Dewey, 2012, p. 13), gave way to the transactional method of teaching, whereby pupils learn through active participation. In the early years of schooling, both teachers and peers play an important role in the pupils' learning process. Due to the fact that interaction with other pupils plays a vital part in learning and in shaping children's personalities as a whole, pupils need to be given opportunities to interact within the schooling process (Peklaj, 2001). Research in other countries has demonstrated that interaction improves interpersonal relations (Sharan \& Shachar, 1988), mental health (Johnson \& Johnson, 2009b) and school performance (Slavin, 1983). You Lv (2014) sums up Chinese research experiences with cooperative learning by stating that this type of teaching motivates students and is conducive to language acquisition and the development of communication skills, creativity and teamwork skills. Lv believes that the practical skills attained form a foundation for the pupils' professional future.

Pupils learn most when they feel comfortable (Papalia, Olds, \& Feldman, 2001; Marjanovič Umek et al., 2004). In the learning process, their motivation is influenced by people around them; in a school environment, these people are teachers and classmates. Classes are artificially formed work groups consisting of pupils of a similar age. The group evolves into a community if every member identifies with it and feels safe and accepted in and by it, which in turn benefits the learning process (Žarkovič Adlešič, 200o). Purposeful management of the process in a way that allows pupils to develop beneficial relationships and mutual affection is the responsibility of every teacher. One of the methods that boosts this process is known as cooperative learning. This teaching method was first utilised in Slovenian primary schools in the 1990s, although it had already been in use elsewhere for several decades. The general theoretical framework 
for cooperative learning was developed by several researchers, and its origins can be found in social interdependence theory (Johnson \& Johnson, 2009a). The cooperative method does not just involve working in groups; it is a carefully planned and moderated process that makes use of cooperation to achieve common goals. In cooperative learning, every person searches for a solution or performs a task that is important to him/her and to every other group member. This method improves results in knowledge areas as well as enhancing cognitive, social, emotional and motivational processes (Peklaj et al., 2001). The present study seeks to determine the planned scope and the realisation of different forms of cooperative learning within the parameters of language education in Slovenian language classes that provide opportunities for peer-to-peer communication, negotiation, exchange of opinions and the like.

\section{The exploration of the significance of cooperative learn- ing in history}

In practice, modern cooperative learning has been crucially shaped by Dewey's theory of education (1915, in Dewey, 2012). Dewey believed that language is a "device for communication" or a tool "through which one individual comes to share the ideas and feelings" with others, and that language is not only a logical instrument, but primarily a social one. When treated as "a way of getting individual information, or as a means of showing off what one has learned" (Dewey, 1915, in Dewey, 2012, p. 12), it is stripped of its social motive and end. Dewey also criticised passivity in learning, the mechanical accumulation of knowledge and monotonous methods that do not actively engage pupils, emphasising that "the active side precedes the passive in the development of the child nature" (Dewey, 1915, in Dewey, 2012, p. 13); he thought it was important to gain experience though direct contact, observation and action. Viewing society as a union of individuals who work together towards a common cause, he believed that schools should be transformed into embryonic forms of social life, claiming that they lacked the conditions for creating a "social consciousness" (Dewey, 1915, in Dewey, 2012, p. 21) that would allow free communication and the exchange of ideas, suggestions and findings about previous successful and failed experiences. Dewey defined mutual assistance as the most natural form of cooperation; rather than being a form of charity, he regarded it as "simply an aid in setting free the powers and furthering the impulse of the one helped" (Dewey, 1915, in Dewey, 2012, p. 21).

The beginnings of social interdependence theory date back to 1900 , when German philosopher Kurt Koffka (Deutsch, 1968, in Johnson \& Johnson, 
2009a) suggested that groups of students were dynamic wholes in which the interdependence among members could vary. His ideas were built upon in the years that followed by Kurt Kewin (1948, in Johnson \& Johnson, 2009a), who believed that in order to accomplish goals, appropriate relationships need to be established between group members. The pursuit of group members' goals triggers cooperation and competitiveness. In order to establish interdependence, there need to be at least two individuals who cooperate with and influence each other. Lewin's work was expanded upon by one of his students, Morton Deutsch (1962, in Johnson \& Johnson, 2009a), who outlined three types of social interdependence: positive, negative and neutral. Deutsch postulated that the type of interdependence influences the way individuals interact as well as the results of the interaction, meaning that their success or otherwise ultimately hinges upon their support and encouragement of each other, or, alternatively, their efforts to discourage and deter each other in working towards their goal(s). He stressed the importance of positive interdependence and personal responsibility in helping to bring about the success of the group in cooperative learning (Deutsch, 1962, in Johnson \& Johnson, 2009a).

In the years leading up to the Second World War, it was found that working in groups was a higher quality approach than working individually, as well as more being effective and productive. This insight served as the basis for the cooperative learning theory formulated by social theorists Gordon Allport, Goodwin Watson, Marjorie Shaw and George Mead (in Gilles \& Ashman, 2003). Johnson and Johnson (2009b) arrived at an important finding by carrying out studies, aided by students and colleagues, on various groups of people (including minors), which showed that there was a stronger link between cooperation and mental health than between competitiveness and mental health. They also found that cooperation more frequently encouraged a higher level of thought (i.e., problem solving, decision-making, critical thinking, creative thought) than did competitiveness or working individually. R. E. Slavin (1983) also conducted a comparative study of cooperative, individualistic and competitive learning at the primary and secondary school levels, and found that, compared to the latter two methods, cooperative learning resulted in better performance in school. It was determined that in order for cooperative learning to work, the group needs clear goals and every member must have clearly defined responsibilities in terms of accomplishing the common goals of the group.

Additional studies by researchers cited later in the article have confirmed the positive effects of cooperative learning on the development of communication skills. Gilles and Ashman (1998) conducted a six-week study involving primary school pupils. By comparing groups of similar age and ability, 
they found that pupils in groups that applied cooperative learning methods performed better in reading, and that their general school performance was superior to that of their peers who did not work in cooperative groups. In a more recent study, Yazdani and Fakhraee Faruji (2013) studied the effects of cooperative learning on the lexical development of immigrant students. The analysis indicated significant differences between the performance of the experimental and the control group. After completing the language course, students who had participated in cooperative learning scored better than those who had learned using traditional methods. The study provides evidence that cooperation is a more effective tool for teaching vocabulary. The researchers believe cooperative learning offers the advantage of providing students in groups with an opportunity to communicate more with each other, to negotiate and to find a common solution. This allows the development of strategies for interpreting and comprehending language as it is actually used by native speakers (Yazdani \& Fakhraee Faruji, 2013). The outcome of a study by Montasser (2014) showed that participants improved their communication and writing skills by applying a cooperative approach, which they believed provided them with a relaxed learning environment. In spite of this, the researcher detected intra-group issues in the process, such as a lack of motivation and ideas concerning working, as well as inactivity on the part of certain individuals owing, for instance, to the fear of making mistakes. The author attempted to alleviate the issue by taking on the role of a moderator in a group, or by allocating different tasks to groups in accordance with the quantum of exercises. This also confirms the findings of Johnson and Johnson (2009b), who determined that the person implementing cooperative learning plays an important role in which s/he is the observer, supervisor and motivator.

\section{Cooperative learning in Slovenian primary schools}

Cooperative learning was systematically introduced in Slovenian primary schools in the 1994-1995 school year as part of the project Modern Psychological Conceptions of Learning and Knowledge and Their Implications for Teaching. An important role in the systematic expansion and promotion of cooperative learning was assumed by Cirila Peklaj (Peklaj et al., 2001), who initially provided training on cooperative learning to teachers and National Education Institute employees, and later published a book as an aid for planning cooperative activities.

Some 15 years ago, Marentič Požarnik (2000) warned that Slovenian schools did not fully utilise the potential for pupils to teach each other. In 
contrast to group work, where not all group members always participate to the same extent, with some hardly participating at all, properly designed cooperative learning elicits active participation from all group members. The process also involves mutual assistance to help all members reach the desired goal(s), emphasising cooperation/interaction between members (Marentič Požarnik, 2000). Vodopivec and Peklaj (2003) suggest that competiveness primarily motivates pupils who already do well, while cooperation is better suited to "lowperforming students who stop fearing failure and have an opportunity to perform well in such a situation" (Vodopivec \& Peklaj, 2003, p. 7).

The Curriculum for Slovenian (Primary School Programme. Slovenian. Curriculum, 2011) is goal-orientated, establishing learning goals that pupils should attain. How they attain these goals is, however, left to the discretion of the teacher, who is at liberty to choose the forms and methods of working, and to independently decide which methods to use in a particular lesson as well as the sequence in which to use them. The curriculum for Slovenian ${ }^{2}$ includes recommendations for instruction, which, among other things, emphasise the need to increase the proportion of cooperative work in Slovenian language classes ${ }^{3}$ by, for instance, working in small groups or pairs, because various kinds of cooperative learning allow pupils to actively develop their skills (e.g., oral competence), higher order thinking skills (problem solving, decision-making, critical thinking, creative thought) and knowledge. Cooperative forms of working are also recommended for teaching children of immigrants and pupils with learning disabilities (Magajna et al., 2008; Kerndl, 2013), and for promoting peer-topeer solidarity (Novak, 2009).

\section{Not every group activity is cooperative}

Dividing pupils into groups does not guarantee that they will cooperate well. American social psychologists and founders of the Cooperative Learning Institute, Johnson and Johnson (1999; Peklaj et al., 2001) compared cooperative and traditional study groups and identified differences between them. Typical characteristics of cooperative study groups were positive connections (interdependence), individual responsibility, group heterogeneity, equal distribution of leadership roles, and a sense of responsibility for one another. Cognitive, social,

2 The Slovenian language as a primary school subject consists of two areas - literature and language - with language instruction taking up $20 \%$ more of the lesson plan than literature lessons (with the exception of Year 1, which has a 50/50 ratio). There are 210 45-minute lessons foreseen for Year 1, 245 lessons in Year 2 and 3, respectively, and 175 lessons per school year in the second three-year primary education cycle (Primary School Programme. Slovenian. Curriculum, 2011).

3 For more on Slovenian as a school subject, see Petek, 2013. 
emotional and motivational goals played a central role. The teacher monitors the pupils' cooperative skills in the process and, if necessary, gets involved in order to teach cooperative skills. Group work ends with a self-evaluation of the group performance. Traditional group work does not involve interdependence or clear responsibilities of individuals. Groups are homogeneous and appoint a leader, with each group member only responsible for his/her own work. Compared to cooperative groups, traditional groups only place emphasis on cognitive goals, while cooperative skills are taken for granted. The teacher focuses on content, and group work does not end in an assessment of its performance. Johnson and Johnson believe that five elements are needed to successfully carry out cooperative learning: positive interdependence, individual and collective responsibility, direct interaction (teamwork), appropriate use of social skills, and evaluation (Johnson \& Johnson, 1994; Johnson \& Johnson, 2009a, 2009b).

Johnson and Johnson ${ }^{4}$ (2009a, 2009b) point out positive interdependence as the most crucial element of cooperative learning, going as far as to say that there is no cooperation without it. Cooperation occurs if all members are aware that every member - and not just the individual member him/herself - benefits from their efforts, and that members thus depend upon each other. Positive interdependence creates the same sense of responsibility for one's own success and for collective success. Everyone is tasked with and responsible for their own assignments and, consequently, the group assignment. Interdependence can, however, also be negative. Positive interdependence involves members mutually cooperating to meet a common objective, whereas members compete amongst themselves to reach the goal set if negative interdependence is established. In the absence of interdependence, members do not cooperate to reach a common goal, usually as a result of oppositional pressure. The second vital element is personal and collective responsibility. All members must bear responsibility for their own contribution towards the common cause. Pupils must realise that working together allows them to achieve more than working on their own would. All members must demonstrate what they have learned in the course of cooperative learning, while also being responsible for the performance and learning of the entire group, thus reducing opportunities for inaction. In order to make members realise that their cooperation and responsibility are vital for reaching the common goal and that the group will fail without their contributions, assignments can be divided between members. Individual responsibility can develop if the performance of every individual is also being assessed. The third element is mutual cooperation or direct interaction

4 The same five elements presented by Johnson and Johnson, who believe them to be the cornerstones of the successful adoption and continuation of cooperative learning, have also been discussed by Ross and Smythe (1995), Brown and Ciuffetelli (2009), Siltala (2010) and Jolliffe (2007), among others. 
within the group; if possible, on an interpersonal level. This occurs when groups members learn together, help each other understand and/or complete assignments as necessary, and encourage and commend one another. Successful cooperative learning requires the development of social and communication skills, as individuals have to gain the interpersonal competencies that allow them to function in a group. These competencies include communication, interpersonal and group skills, such as listening, coordination, providing and receiving help, leadership, decision-making, establishing and fostering trust, the ability to settle disputes, etc. (Johnson \& Johnson, 2009a, 2009b). Jolliffe (2007) holds that groups should be composed of four members. If there is an uneven number of pupils, there should be three or five members per group. Six-member groups, however, are not recommended, as the group usually splits into two parts and contact between members ceases. A practical configuration is having members work together in pairs at first, then merging two pairs together, only for a short time at first, but for longer periods of time once they develop the necessary skills. In light of research findings, Jolliffe recommends not changing the composition of groups for five to six weeks (Jolliffe, 2007). The final important element of cooperative learning is evaluation. After completing the assignment, group members discuss their performance, the results of their assignment and the relationships in place while working in a group. Every group has to report on its results as well as on how well members worked together and the positive and negative aspects of working together (Johnson \& Johnson, 1999, 2009a, 2009b; Peklaj et al., 2001).

Peklaj (2000) also remarks that, when organising cooperative learning, the following should be taken into account: positive interdependence between group members, direct interaction between members during the entire working process within a group (planning, discussion and assessment of results), the heterogeneous composition of groups (in terms of knowledge, gender, social or ethnic affiliation, or by way of assigning different roles to each member, or in terms of cognitive, emotional, motivational and social goals) and clearly defined responsibilities of each member. Peklaj stresses that, in order for the group to function, it is necessary to establish common rules that are observed by all members, thus ensuring there are no interruptions or disagreements. She recommends changing the composition of the groups for optimal performance.

\section{The role of the teacher}

The role of the teacher in schools is not limited to conveying knowledge to the pupil; it is also concerned with ensuring the quality of lessons and facilitating effective learning. Teachers must provide the best possible conditions for 
the social, emotional and spiritual development of their pupils (Peklaj et al., 2001; Vodopivec \& Peklaj, 2003). This development cannot attain optimal levels merely by direct instruction and individual work; effective cooperative learning strategies should be implemented "in combination with other forms of teaching" (Lv, 2014, p. 1952). When applying the method of direct instruction, the teacher acts as a mere conveyor of curriculum content, while pupils are often mere listeners ${ }^{5}$ and are given limited opportunities to speak. Since individual learning involves independent work, this method also affords pupils only limited opportunities for communication and cooperation with their peers. Accordingly, pupils gain less experience, including the kind of experience that affects the development of mutual respect and tolerance and the acceptance of diversity. The modern school system focuses on experiential learning (Žarkovič Adlešič, 2000), a method that allows the pupil to learn in the process of transforming experience (Požarnik, 1992; Žarkovič Adlešič, 200o). For this reason, the author holds that relationships cannot improve simply as the result of a lecture on tolerance.

One of the roles of the teacher is that of a motivator and, as such, the teacher must believe in the power of cooperative learning. The teacher's own certitude and enthusiasm positively affects the pupils, who realise that cooperation allows them to achieve more. Assigning specific tasks to individuals strengthens their awareness of the importance of their contributions and of the responsibility they bear for reaching the common goal (Žarkovič Adlešič, 2000).

Due to the fact that cooperative learning also involves the acquisition of social skills, the teacher must first be familiar with approaches and strategies for teaching these skills to pupils. S/he must know how to establish positive interdependence and must encourage responsible behaviour on the part of every group member, as well as ensuring mutual cooperation between members, the appropriate use of social skills, and group processing in learning situations (Johnson \& Johnson, 2009a).

Fostering members' understanding and acceptance of one another, as well as successful communication, requires the development of a sense of belonging to the class, making the teacher's role as the creator of the class atmosphere indispensable. The teacher should ensure a safe, trusting and tolerant classroom environment. Cooperation requires good relationships between peers and a degree of familiarity. The teacher is responsible for establishing and encouraging

5 Pregel Plut (2012) believes that one-sided listening requires great effort on the part of the listener, which is ineffective as "pupils cannot remember great information loads and simultaneously process them" (Pregel Plut, 2012, p. 89). 
new contacts and must provide pupils with opportunities to get to know one another (Vodopivec \& Peklaj, 2003; Johnson \& Johnson, 2009a). Positive experiences gained during class make the child more motivated, which is a key factor in accelerating knowledge acquisition. The teacher should be aware that the "class" constitutes an opportunity to encourage communication between peers, and that working cooperatively in groups or pairs promotes "the acquisition of language knowledge /.../ and the development of communicative competence" (Lv, 2014, p. 1952). Marentič Požarnik and Plut Pregelj (2009) emphasise the importance of developing language skills through classroom discussions, and believe that language competence "can only be developed by using language" (Marentič Požarnik \& Plut Pregelj, 2009, p. 60). By gaining positive communication-specific experience within a group and being well received by peers, the pupil will feel (even) more relaxed and will be motivated to cooperate and communicate in the future. On acquiring negative experience, however, the pupil will avoid furthering contact and participating in cooperative work and communication, thereby affecting his/her emotional and social development and hampering the development of his/her communication skills. Increasing the number of contacts also infers a proportionate increase in familiarity; more contacts result in new acquaintances, which in turn result in more frequent communication. If pupils are more familiar with one another, there is a greater likelihood of individuals and their needs being met with understanding. Direct contact also means greater compassion/ empathy (Peklaj, 2001; Hedge, 2005). More frequent use of language/speaking helps transform individuals' passive lexicon into active vocabulary, while a richer vocabulary results in greater comprehension of spoken and written language and better speaking and writing skills (Gabrijelčič, 1993).

Johnson and Johnson (2009b) state that the responsibilities of the teacher prior to implementing cooperative learning include formulating educational and social objectives, planning group sizes, determining the criteria for forming groups, defining the roles to be accorded to individual group members, catering to the equipment needed to complete the assignments, and organising the classroom. The latter process should allow the teacher unrestricted access to each group and a view of the activities of each individual. The teacher must also provide the pupils with instructions on how to complete the assignment and must explain the characteristics of cooperative work, as well as outlining the assessment criteria and social skills to be used by the pupils. During this process, the teacher acts as an observer, monitoring the work of the pupils, and, if necessary, also takes on the role of mediator and assistant, collecting feedback on reorganising groups. The teacher follows the pupils' discussions in order to obtain information on how well they get along with each other and who is tasked with which responsibility. 
In the final phase, the teacher evaluates the quality and quantity of each individual pupil's efforts and helps them evaluate themselves by moderating a discussion on what they have learned and how well they have worked together, while also encouraging them to suggest improvements (Johnson \& Johnson, 2009b).

The teacher is also responsible for the organisation and appropriateness of the classroom setting. An appropriate classroom situation provides pupils with the opportunity to communicate with their peers (Peklaj, 2001); the teacher, however, cannot achieve this by being solely focused on the objective and must also focus on the process of meeting the objective, i.e., the teaching process.

\section{Cooperative learning in Slovenian language classes - language teaching}

“A key factor for developing the pupils' communication skills is communication, which should be deliberately and systematically developed in language classes" (Bešter Turk, 2011, p. 123). Due to the large number of pupils per class, resulting in fewer opportunities for everyone to express their opinion, it is important that "pupils do not learn from their teacher alone but rather also from peers and through talking to peers" in school (Plut Pregelj, 2012, p. 110). Cooperative learning is one of the teaching methods that are specifically referenced in the Curriculum for Slovenian recommendations for instruction (Primary School Programme. Slovenian. Curriculum, 2011); it is one method that can, in our experience, be used in language teaching regardless of the type of communication activity ${ }^{6}$ or the aspect of communication competence ${ }^{7}$ that the teacher wants to cultivate in the lesson.

Every instance of successful cooperation, including cooperation in language classes, requires the creation of a set of rules to be adhered to in order to ensure a smooth working process (Peklaj, 2001), and, as stated by Žarkovič Adlešič (200o), in order to "protect the children's rights to learn and be safe, respected and heard" (p. 83).

Cooperative learning involves pupils working towards a common goal. They can do their assignments in groups over a certain period of time or in temporary groups that last anywhere from a couple of minutes to an entire class period (Johnson \& Johnson, 2009). The former means that pupils are grouped

6 Pupils are supposed to practically and creatively master all four communication activities, i.e., listening, speaking, reading and writing (Primary School Programme. Slovenian. Curriculum, 2011).

7 The building blocks of communication competence include: motivation to receive and express messages, factual/encyclopaedic knowledge on the part of the sender and the receiver, "language competence (i.e., designatory, explicatory, pronunciation and spelling competence), nonverbal communication, pragmatic and metalinguistic competence /..."” (Bešter Turk, 2011, p. 124). 
in permanent heterogeneous, cooperative groups with no changes in membership, while the latter sees constant shuffling of team members for specific tasks. Although the authors do not specifically mention these methods in language classes, they can also be used in such settings.

The type of cooperative learning in cooperative groups that can be realised over the course of one or two class periods includes the so-called "jigsaw model” (Marentič Požarnik, 200o, p. 240), which allows all members to actively participate by focusing on only a portion of the group topic, so that in order to describe an animal, for example, the first member collects information on its external characteristics, the second on its nutrition, the third on its reproduction, the fourth on its habitat, the fifth on its special features, etc. All members have to first present their research to the rest of the group. Members can help each other, offer each other advice, etc. in the process. The objective is to create a diagram, which is one of the phases ${ }^{8}$ of compiling a monologic text. ${ }^{9}$

\section{Empirical study}

Cooperative learning can be planned and carried out with specific reference to a number of different areas and with pupils of all ages. The present applied empirical study focused on language teaching in Slovenian language classes as taught in Year 1 through Year 5 of primary school.

\section{Purpose}

Studies by several researchers (Johnson \& Johnson, 1985; Nicolas \& Miller, 1994; Lazarowitz, Hertz-Lazarowitz, \& Baird, 1994) have demonstrated that cooperative learning affects pupils' interest in learning, their self-image and their attitude towards the subject. Sharan and Shachar (1988) proved that cooperative learning also affects learning about tolerance, with pupils who participated in heterogeneous groups improving their relationships with fellow pupils belonging to, for example, other ethnic minorities: they socialised with these children more often, had more friends from the other ethnic group and maintained friendships with them over a longer period of time. It is our belief that the current Slovenian practice overemphasises learning objectives and pays too little attention to the communication process in learning, that there is still a (too wide) gap between the concept of cooperative learning and

8 When formulating a monologic text, pupils should follow the following stages in this order: invention, disposition, elocution, revision and transcription of the revised text (Križaj Ortar, Magajna, Pečjak, \& Žerdin, 20oo; Bešter Turk \& Križaj Ortar, 2009). 
its implementation in primary schools, and that primary school pupils are not offered enough forms of cooperative work in the first and second three-year cycles of primary education. More frequent socialising with peers through cooperative work can facilitate more frequent communication, which can positively affect the development of communication skills. Since more immigrants settle in Slovenia with each passing year, we believe cooperative learning is also one of the most vital methods for fostering acceptance and tolerance; it is an important method of working that provides more opportunities for communication.

The present study sought to identify the forms of cooperative learning in language education during the first and second three-year cycles of primary education, with a specific focus on the proportion of work carried out in groups and pairs, and the proportion of work in groups or pairs executed following the principles of cooperative learning rather than those of traditional methods.

The following questions were asked:

- Do teachers plan work in pairs or groups in language classes? If so:

- Where is this type of working methodology more widespread, in urban or rural schools?

- In which school year is it implemented?

- At what point in the class period do teachers apply it?

- Which method is being used, the traditional or the cooperative method?

- How many years of work experience do the teachers who apply the methodology of working in pairs or groups have?

\section{Research method}

The study used a descriptive method for an experiment in education. The data were obtained by shadowing and via audio recordings of language classes.

\section{Execution}

Recordings of language classes were carried out between November 2013 and January 2014, followed by transcription and analysis.

\section{Sample and data processing}

The recorded lessons were ad hoc samples and included 46 teachers with varying degrees of experience (Graph 1). Most of the respondents (37\%) had between 21 and 30 years of professional experience; half of them had up to 20 
years of professional experience, and half had over 20 years of professional experience. They worked at primary schools in various regions of Slovenia: 26 teachers (57\% of all respondents) taught at schools in urban areas, while 20 taught at rural schools (Graph 2). During the 2013-2014 school year, all of the respondents taught a class within the first or second three-year cycle of primary education (Graph 3).

After the 46 audio recordings were transcribed, the data were processed. The transcriptions were first analysed for data on the teaching methods that were applied in the opening, central and closing phases of the lessons in urban and rural schools in Years 1 to 5, respectively. The professional experience of the teachers who applied the teaching method was then examined, followed by a closer analysis of the process of working in groups and pairs. It was determined whether the teaching methods applied were traditional or cooperative. This was done based on the teacher's instructions before and after the teaching method was applied, with special attention being paid to the apportioning of assignments to groups/pairs, to the question of whether the method encouraged cooperation between members, and to the final showcasing/report on the work of the groups and pairs. The results of the study are illustrated with diagrams for greater clarity.

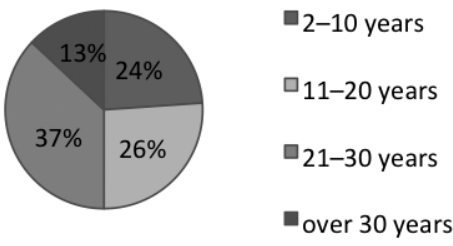

Graph 1. Proportion of teachers by years of professional experience

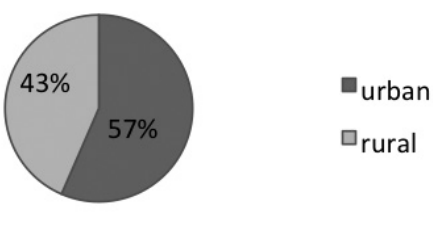

Graph 2. Type of school that the respondent teachers taught at
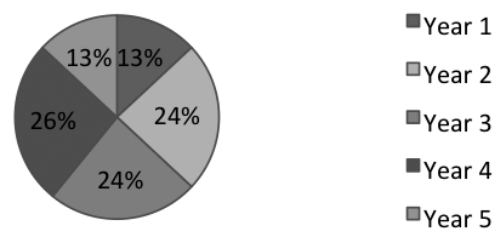

Graph 3. Proportion of teachers by the year taught 


\section{Study results}

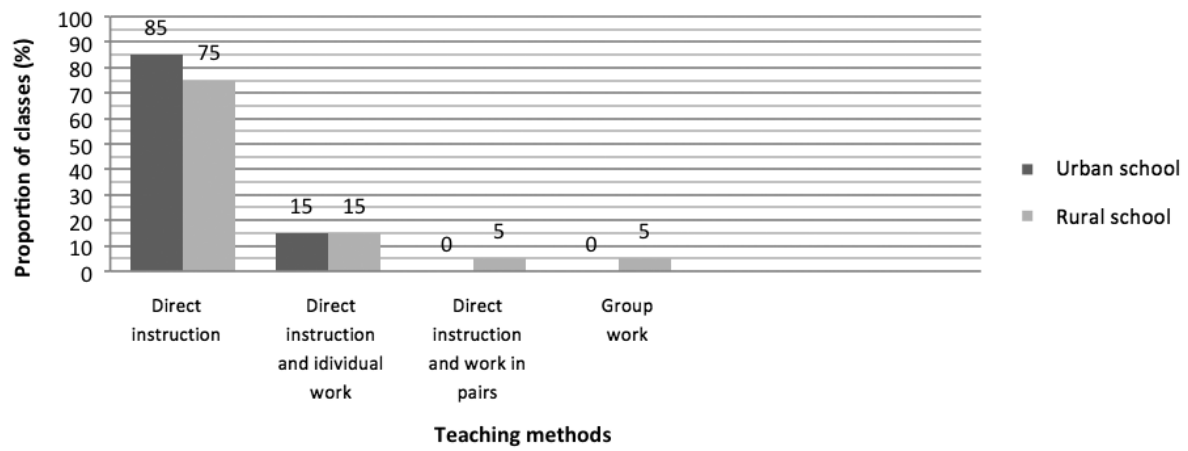

Graph 4. Teaching methods applied in the first phase of a language class in urban and rural schools

The initial phase of Slovenian language classes in urban and rural schools most frequently involved direct instruction ( $85 \%$ in urban schools and $75 \%$ in rural schools, respectively). Only two teachers in a rural school ( $4 \%$ of the sample) applied cooperative teaching methods or working in pairs during the initial phase of the lesson. No language class in urban schools involved cooperative teaching methods or working in pairs.

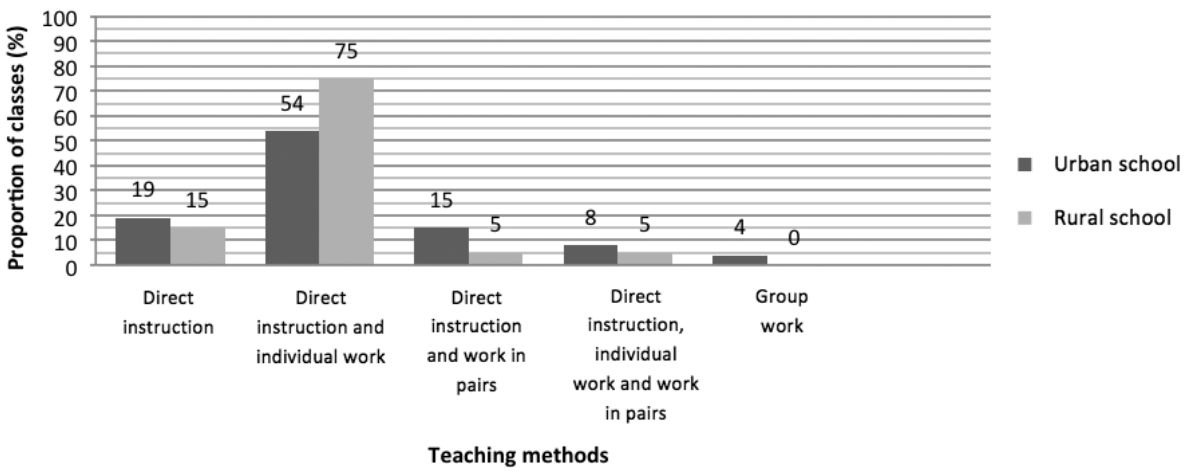

Graph 5. Teaching methods applied in the intermediate phase of a language class in urban and rural schools

Graph 5 shows that the intermediate phase of language classes in urban and rural schools was dominated by direct instruction, most frequently combined with individual work. Compared to the initial phase of the class, there was 
more individual work (47\% more in urban and 65\% more in rural schools) and slightly more work carried out in pairs and groups (15\% and $12 \%$ more, respectively), although only in urban schools. In spite of this, these teaching methods remain the least frequently applied in the intermediate phase of the class as well, being predominantly applied by urban school teachers: 7 out of 9, or $15 \%$ of the sample. Pupils worked in pairs in $15 \%$ of urban schools and $5 \%$ of rural schools, and worked in groups in $9 \%$ of urban schools and $5 \%$ of rural schools. All rural school teachers chose to apply the direct instruction method to the intermediate phase of their lessons, with more than half (80\%) also applying the method of individual work and/or working in pairs and/or group work.



Graph 6. Teaching methods applied in the concluding phase of a language class in urban and rural schools

The concluding phase of language classes also most frequently featured direct instruction (in $81 \%$ of urban schools and $75 \%$ of rural schools), followed by a mix of teaching methods, i.e., direct instruction and individual work, and individual work alone. As in the initial phase, direct instruction alone was again more common in urban schools $(46 \%)$, as was group work $(8 \%)$, while rural schools had a higher incidence of individual work alone (60\%) and working in pairs (5\%). Contrasting diagrams 5 and 6 , an outlier ${ }^{10}$ individual work unit in the concluding phase can be observed, which amounts to $15 \%$ of all lessons (11\% in urban and $20 \%$ in rural schools). In over half of the language classes, or $42 \%$ of lessons in urban and $60 \%$ of lessons in rural schools, the individual work method was applied. This was probably due to a test at the end of the lesson aimed at determining pupils' comprehension of the material handled. In only five lessons ( $11 \%$ of all lessons) did pupils have an opportunity to learn in pairs or groups in the concluding phase. Their proportion in urban and rural schools

10 The reference here is to a class that only featured individual work for its entire duration. 
is comparable, with three such lessons (12\%) in urban schools and two such lessons $(10 \%)$ in rural schools.

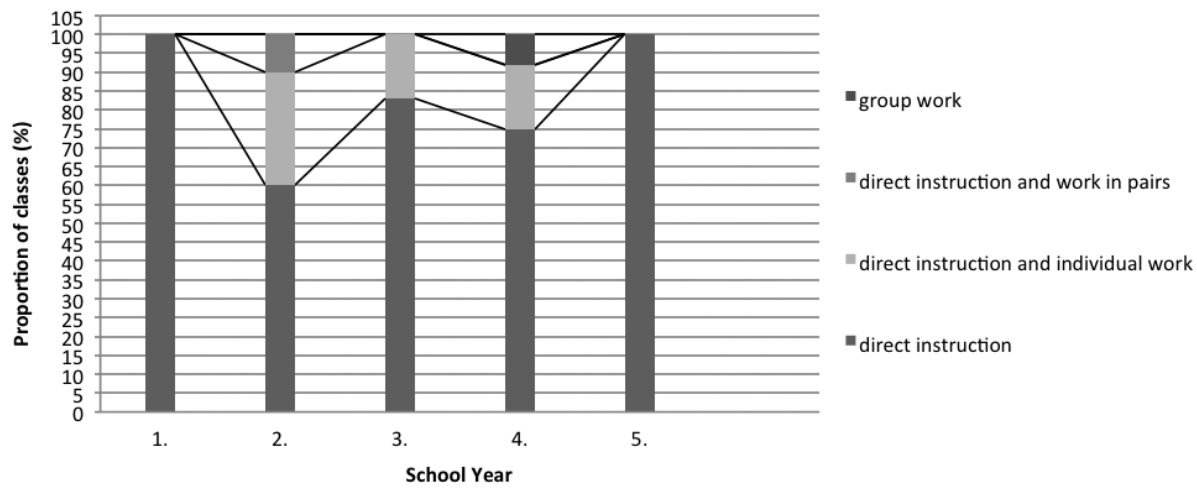

Graph 7. Initial phase of classes: teaching methods by school year

In Years 1 and 5, initial phases of classes only featured direct instruction. This teaching method also dominated lessons in Year 2 (60\%), Year 3 (83\%) and Year 4 (75\%). The greatest number of teaching methods (three) was used in Year 2 and Year 4, the method of working in pairs was applied in one Year 2 class (representing 10\% of Year 2 classes), while group work took place in one Year 4 class (which equates to $8 \%$ of all Year 4 classes).

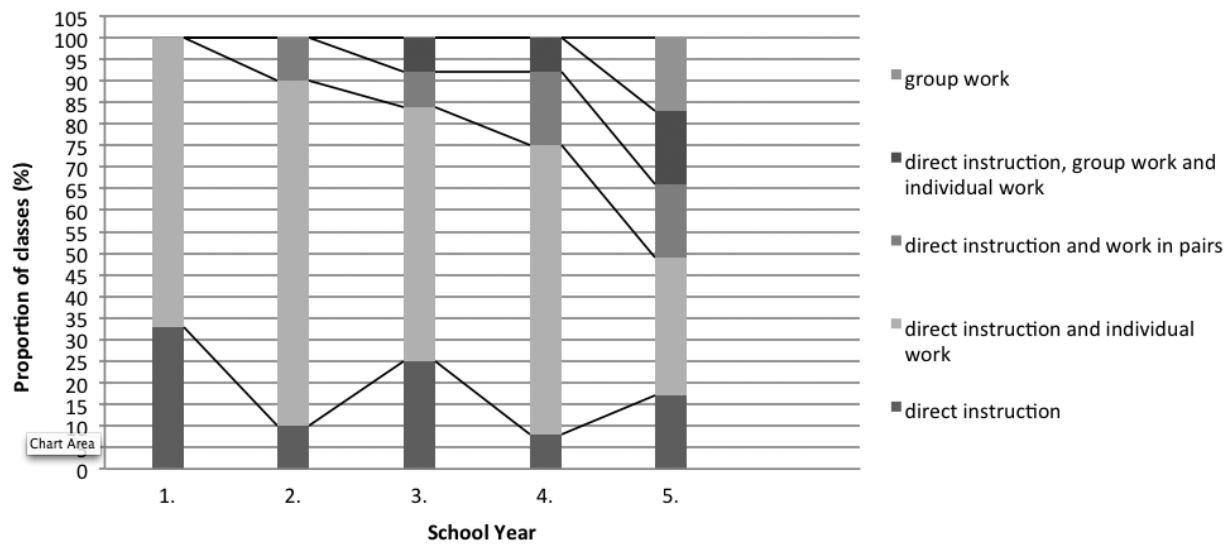

Graph 8. Intermediate phase of classes: teaching methods by school year

The intermediate phase of language classes in all years predominantly featured direct instruction and individual work. In terms of the number of 
respondent classes in each year, Year 1 classes were most likely to experience direct instruction alone (33\%), with Year 4 classes least likely to be exposed to direct instruction alone $(8 \%)$, while Year 2 classes were most likely to be taught applying the methods of direct instruction and individual work (80\%), followed by Years 1 and 4 (67\%, respectively), with this scenario being the least likely in Year $5(32 \%)$. Year 1 pupils did not work in pairs at all, while both Year 1 and Year 2 pupils were given no opportunity to work in groups. There was only one Year 5 class $(17 \%)$ in which pupils worked in groups for the entire intermediate phase of the class. As Graph 8 shows, the diversity of teaching methods used in language classes increases with the age of the students.



Graph 9. Concluding phase of classes: teaching methods by school year

The concluding phase of language classes exhibited the greatest variety of teaching methods. The frequency of direct instruction increased with school year, while individual work became less frequent. Among the respondent classes, the percentage of direct instruction was highest in Year 5 (66\%), followed by Year 4 with $58 \%$. Similar trends were observed with regard to the combined application of direct instruction and working in pairs. In proportion to the number of respondent classes, the ratio was highest in Years 1 and 2 (50\%, respectively), followed by Year 3 with $33 \%$ and Year 4 with $25 \%$. The method of working in pairs was applied in the concluding phase of one class in Year 4, while one Year 5 class ended with group work. As Graph 9 shows, the concluding phase had the highest incidence of the method of working in groups and pairs in older groups, i.e., Years 4 and 5, which was also the case with the intermediate phase of language classes. 




"group work

"direct instruction and work in pairs

"direct instruction and individual work

"direct instruction

Graph 10. Initial phase of classes: teaching methods by teachers' professional experience

Teachers with 2-10 years of professional experience employed the greatest variety of teaching methods in the initial phase of their classes. Only two teachers (18\%) from this group applied the method of working in pairs or groups; one of them complemented direct instruction with working in pairs, while the other did the same with group work. All teachers with 11-20 years of professional experience made use of direct instruction alone, as did five (83\%) of the teachers with more than 30 years of professional experience. The majority of teachers with $21-30$ years of professional experience $(76 \%)$ included both direct instruction and individual work in the initial phase of their classes.

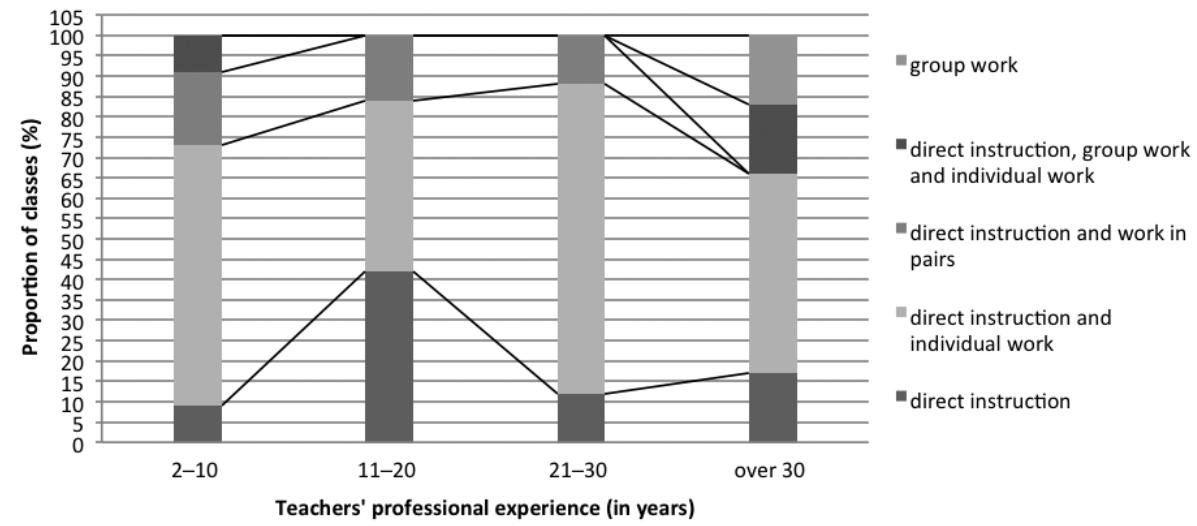

Graph 11. Intermediate phase of classes: teaching methods by teachers' professional experience 
The intermediate phase of the class saw an increase in the variety of teaching methods used irrespective of the teachers' professional experience. Teachers with 2-10 years of professional experience applied the widest array of teaching methods. As above, direct instruction was most commonly applied by teachers with 11-20 years of professional experience (42\%). Teachers with $21-30$ years of professional experience $(76 \%)$ were again the most likely to apply both direct instruction and individual work. No teacher with more than 30 years of professional experience tried to apply the method of working in pairs, while two teachers with 2-10 years of professional experience (18\%), two teachers with $11-20$ years of professional experience (16\%), and $12 \%$ of teachers with 21-30 years of professional experience did attempt to apply this method. Only one teacher with more than 30 years of professional experience organised group work.

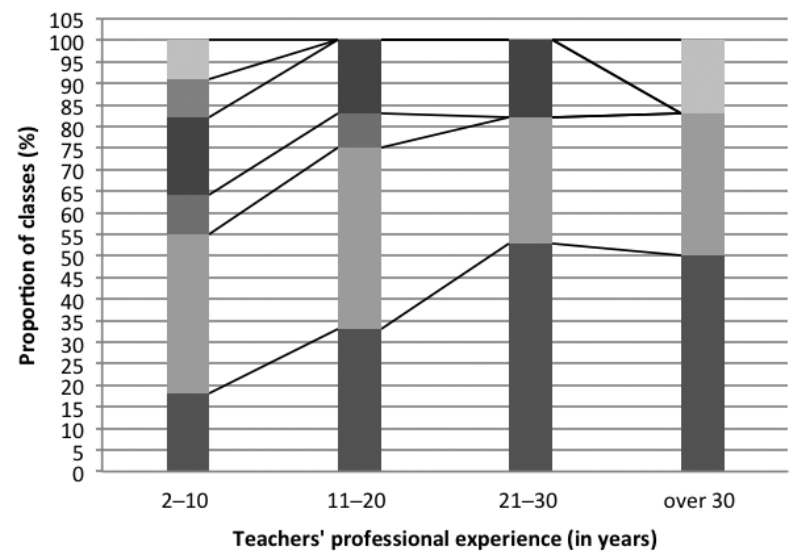

"group work

work in pairs

"individual work

"direct instruction and work in pairs

"direct instruction and individual work

- direct instruction

Graph 12. Concluding phase of classes: teaching methods by teachers' professional experience

During the concluding phase of the class, it was teachers with 2-10 years of professional experience who employed the greatest variety of teaching methods. The highest proportion of the same group of teachers (18\%) also featured group work or working in pairs in their classes, with one (9\%) applying only the method of working in pairs and one ( $9 \%$ ) combining it with direct instruction. Only one teacher concluded her class with group work; she had over 30 years of professional experience and had already used group work in the intermediate phase of the class. 


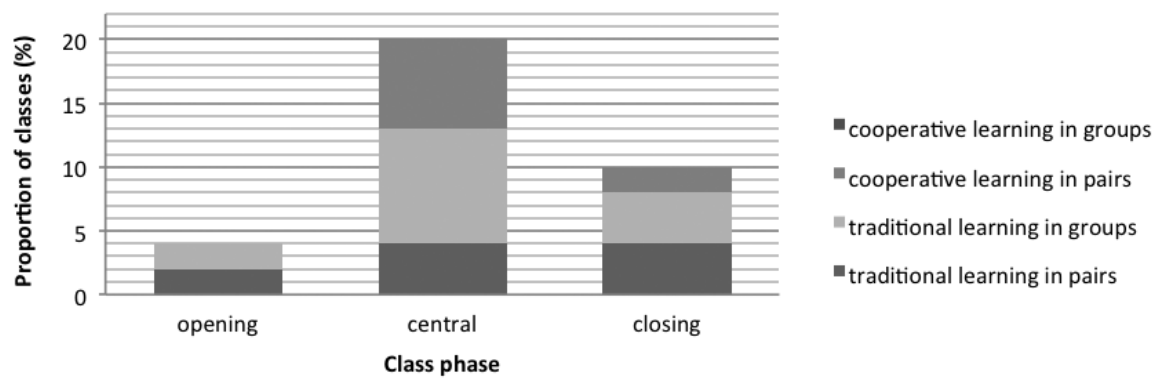

Graph 13. Type of learning in pairs and groups

Working in pairs or groups was used as a teaching method in 14 language classes (30\% of all classes), with this figure accounting for the fact that group work encompassed both intermediate and concluding phases of the class in two instances (4\%). Cooperative learning in groups or pairs only took place in four language classes ( $9 \%$ of all classes), while traditional learning in pairs or groups occurred in ten classes ${ }^{11}$ (22\% of all classes). Cooperative learning was only effected when working in pairs, with no instance of cooperative work in groups. Cooperative learning was most frequent in the intermediate phase of the class $(7 \%)$, followed by the concluding phase $(2 \%)$, with no instances thereof documented in any initial phases. Furthermore, cooperative learning never spanned the entire lesson and was always combined with direct instruction.

\section{Interpretation of key results}

The results of the study indicate that teachers do include the methods of working in pairs and groups in their language classes; however, these teaching methods are much less prevalent than direct instruction and individual work. Teachers continue to prefer direct instruction throughout the lesson when teaching Slovenian language classes (be it during the initial, intermediate or concluding phase). The greatest variety of teaching methods can be found in the concluding phase of the class, with the least variety being evinced in the initial phase. If teachers plan activities in groups or pairs, they tend to place such activities in the intermediate phase of the class, with placement in the initial phase being favoured least. Despite the various options available to them, teachers most frequently initiate the lesson with a direct, instruction-driven discussion to motivate pupils to undertake work; openers include: "So, children, what have we discussed in the past couple of Slovenian classes?" or: "So,

11 This figure also accounts for the fact that group work encompassed both intermediate and concluding phases of the class in two instances $(4 \%)$. 
we will take a look at a couple of words today that I think you are already familiar with /.../ Is there a difference between these two words?", or: "We have talked about farms this whole week. /.../ Now, can anyone tell me what a farm actually is?" Applying the methods of individual work and direct instruction, teachers use the concluding phase of the lesson to test how well the pupils have grasped the material. Examples include: “So, let's read your answers. Let's go one by one /.../", "Now, you will do this assignment. Each one of you must do the assignment on your own; you each need to write your own short summary /.../", "I will now explain what you need to do next. This is an individual assignment, an exercise in your workbooks. /.../" Quizzing by the teacher, whether at intervals during the lesson lasting a couple of minutes or during the concluding phase of the lesson, can be replaced with peer quizzing in pairs, with pupils attentively listening to each other's answers/solutions, discussing any differences in their answers, supporting their decisions with arguments and working together to find or confirm the correct or appropriate solution.

With regard to learning in pairs and groups in the urban and rural school setting, the study has uncovered no significant differences. Rural schools performed better in the initial phase of classes, while urban schools did better in the intermediate and concluding phases. There was a $9 \%$ difference in performance. The school environment, be it urban or rural, seems to have no significant effect on how frequently a teacher applies a certain teaching method; the choice seems to be primarily a matter of personal preference. Teachers with more years of professional experience applied fewer types of teaching methods. The study showed that the method of working in pairs and groups was most often chosen by teachers with 2-10 years of professional experience during all phases of the lesson. There may be several reasons behind this choice. It may be driven by the content taught in the lesson; however, the age of the pupils and the motivation for implementing cooperative teaching methods seem to be more common causes, as preparation for cooperative learning tends to be more challenging and time consuming than preparation for direct instruction or individual work.

Relative to the number of classes included in the study, Year 5 pupils, i.e., older children, constituted the group most frequently working in pairs or groups. The most common causes for avoiding cooperative learning seem to be time constraints and potential issues with managing children, since working in groups or pairs involves a higher risk of conflict and disagreements than direct instruction or working individually, and requires teachers to expend more energy and time and to act as competent mediators.

The study confirmed our postulations and the hypothesis by Marentič Požarnik (200o), who believes that cooperative learning continues to be an 
underused method in Slovenian schools; learning in pairs and groups tends to be traditional rather than cooperative. In all instances of cooperative learning in pairs, pupils engaged in role play: they were asked to discuss the assignment in pairs and then act out two simultaneous or separate actions or a phone conversation or a situation that required them to apologise. This is evident in the transcription of the audio recording in question: "/.../ I want you to have a discussion in pairs, make a decision in pairs about who will call and who will pick up the phone. /.../", "Have you formed pairs yet or do you want me to assign you partners? /.../ You will act out a phone conversation. /.../ One of you will play the caller and the other one will answer the phone. /.../" Each performance was followed by an evaluation led by the teacher, usually by asking the audience questions to prompt them to evaluate the performance, such as: " $/ . . /$ Did they do a good job acting out this scenario? Should they have been more polite?" or: "After your classmates act out their parts in front of the class, we will discuss their performance. Now listen very closely. /.../ Did Petra apologise correctly?" None of the instances involved evaluating the experience of working in a group, although this would be advisable in future evaluations in order to improve cooperative learning.

A number of authors (Peklaj et al., 2001; Johnson \& Johnson, 2009a; Sharan, 2010) believe that the apportionment of responsibilities as well as interdependence are vital in cooperative learning, as is the awareness that every pupil is responsible for his/her own contribution to the success of the pair or group. The audio recordings of lessons reveal that teachers who applied the cooperative learning method gave pairs detailed instructions face-to-face, ${ }^{12}$ making it clear that the method of working in pairs was applied to ensure that both pupils cooperated with each other and contributed to the successful completion of the task, for example: " $\% / . . /$ Now your job is to work in pairs with the person sitting next to you /.../ Your job is to form a sentence that includes an action that occurs after a different action, and two actions that happen at the same time. You will then mime the action to your partner, who will have to guess what your sentence says /.../" Traditional teaching methods do not involve a clearcut apportionment of work, such as "You will form groups of four. Every group takes their two sheets of paper and does the following. First, you make sure the pictures are in the correct order. If a picture is in the correct place, you place a tick alongside it; if not, you cross it out. In the second part of the assignment, you will write a word under each picture, describing what is in the picture in a single word. Any questions? Once you are done, you will bring both sheets of paper back and place them where they are now on the magnetic board. You don't have to push each other around to do that." Or "/.../ Then every group gets

12 Two of them also issued instructions in writing, as different pairs had different assignments. 
a sheet of drawing paper. /.../ One of you will be the scribe. Or more of you. /.../ First read the question. You have your pictures next to you, and you can find some more, alright? You need to have at least ten of them. /.../ Look, every group has a marker pen, you can also use your own. /.../ Each group will present their assignment and their questions." A proper implementation of cooperative group work would need to involve the teacher assigning specific roles to each member of the group (e.g., the supplier, ${ }^{13}$ the reader, the scribe, the reporter) or having the group members assign roles to each other. Even so, every member should have suggested two adjectives, which would be followed by an exchange of opinions and by one of the members writing down the choices agreed upon in the group.

\section{Conclusion}

The results of the study suggest that Slovenian pupils in language classes in Years 1 through 5 all too often remain passive listeners instead of actively participating in the learning process, as stressed by Sharan (2010). The present article aims to raise awareness among teachers about the importance of cooperative learning, and to reduce the current proportion of direct instruction as the dominant teaching method in primary school language classes in favour of (cooperative rather than traditional) learning in pairs and groups. We believe that the systematic and consistent use of cooperative teaching methods would improve cooperation in the classroom, thereby reducing conflict between peers. We concur with You Lv, who says that learning new skills by cooperative learning allows students to "lay a necessary foundation for the future" (Lv, 2014, p. 1952). We hold that it is vital for language teaching to promote verbal communication by way of applying the method of cooperative learning, and that the more frequent application of this method would positively affect the development of individuals' communication skills. The dominance of direct instruction has resulted in an excessive proportion of communication taking place between pupils and the teacher, while communication between pupils remains exceedingly rare. The teacher speaks most of the time, while the pupils are given only infrequent opportunities to speak, express their opinion and develop cooperation skills. Given that socialisation provides more opportunities to communicate and acquire language skills, we believe that introducing cooperative learning would also be beneficial in classes that include children with a poor or inadequate grasp of the Slovenian language.

13 The person who provided the group with supplies needed to complete the assignment, for example. 
Several teachers, participants in this study, and Cirila Peklaj (Peklaj et al., 2001), who has published a number of lesson plans with her colleagues, ${ }^{14}$ have proved that language classes provide opportunities to create a supportive learning environment, implement a variety of cooperative teaching methods and foster cooperation, something that is vital for every individual, since cooperation is a crucial element of everyday life, whether we like it or not. Since there are no regulations on when and how often the method should be applied, the teacher should exercise his/her own discretion in this regard.

\section{References}

Bešter Turk, M. (2011). Sporazumevalna zmožnost - eden izmed temeljnih ciljev pouka slovenščine. Jezik in slovstvo, 56(3/4), 111-130.

Bešter Turk, M., \& Križaj Ortar, M. (2009). Priročnik za učitelje - uvod. Za slovenščino v 4., 5., 6., 7., 8. in 9. razredu osnovne šole. Ljubljana: Založba Rokus Klett. Retrieved 05.03.2014 from http://www. devetletka.net/resources/files/doc/test/OS_slovenscina/7.\%2orazred/Prirocniki_priprave/PR\%20 za\%2oucitelje\%2oUVOD.pdf

Brown, H., \& Ciuffetelli, D. C. (2009). Foundational methods: Understanding teaching and learning. Toronto: Pearson Education.

Deutsch, M. (1962). Cooperation and trust: Some theoretical notes. In M. R. Jones (Ed.), Nebraska symposium on motivation (pp. 275-319). Lincoln: University of Nebraska Press.

Deutsch, M. (1968). Field theory in social psychology. In G. Lindzey \& E. Aronson (Ed.), The handbook of social psychology. 1 ed. (pp. 412-487). Reading, MA: Addison Wesley.

Dewey, J. (1915). The school and society. Chicago, IL: University of Chicago Press.

Dewey, J. (2012). Šola in družba. Goran Gaber (trans.). Ljubljana: Pedagoška fakulteta.

Gabrijelčič, M. (1993). Bogatimo besedni zaklad - z miselnimi vzorci. Ljubljana: Državna založba Slovenije.

Gilles, R. M., \& Ashman, A. F. (1998). Behavior and interactions of children in cooperative groups in lower and middle elementary grades. Journal of Educational Psychology, 9o(4), 746-757.

Gilles, R. M., \& Ashman, A. F. (2003). Cooperative Learning: The social and intellectual Outcomes of Learning in Groups. London: Farmer Press.

Hedge, T. (2005). Writing. Oxford: Oxford University Press.

Jacobs, G. M., Lee, C., \& Ng, M. (1997). Cooperative Learning in the Thinking Classroom. Research and Theoretical Perspectives. Retrieved 05.03.14 from http://files.eric.ed.gov/fulltext/ED408570.pdf Johnson, D. W., \& Johnson, R. T. (1985). Classroom Conflict. Controversy Versus Debate in Learning Groups. American Educational Research Journal, 22(2), 237-256.

Johnson, D. W., \& Johnson, R. T. (1999). Learning together and alone. Cooperative, competitive, and

14 Lesson plans featuring the cooperative learning method were drawn up by primary school teachers who had applied the method in Slovenian language classes. 
individualistic learning. Boston: Allyn \& Bacon.

Johnson, D. W., \& Johnson, R. T. (2009a). An Educational Psychology Success Story: Social

Interdependence Theory and Cooperative Learning. Retrieved 20.05.2014 from http://www.co-

operation.org/wp-content/uploads/2011/o1/ER.CL-Success-Story-Pub-Version-o9.pdf

Johnson, D. W., \& Johnson, R. T. (2009b). Introduction to Cooperative Learning. An Overview Of

Cooperative Learning. Retrieved 13.03.2014 from http://www.co-operation.org/home/introduction-tocooperative-learning/

Jolliffe, W. (2007). Cooperative Learning in the Classroom: Putting It into Practice. London : SAGE

Publications.

Kerndl, M. (2013). Diferenciacija in individualizacija pri pouku književnosti v tretjem triletju osnovne šole. Doktorska disertacija. Ljubljana: Pedagoška fakulteta.

Križaj Ortar, M., Magajna, L., Pečjak, S., \& Žerdin, T. (2000). Slovenščina v 1. triletju devetletne osnovne šole. Trzin: Izolit.

Lazarowitz, R., Hertz - Lazarowitz, R., \& Baird, J. H. (1994). Learning Science in a Cooperative

Setting: Academic Achievement and Affective Outcomes. Journal of Research in Science Teaching, 31(10), 1121-1131.

Lee, C. et al. (1997). Cooperative Learning in the Thinking Classroom. Research and Theoretical Perspectives. Retrieved 05.03.2014 from http://files.eric.ed.gov/fulltext/ED408570.pdf

Lewin, K. (1948). Resolving social conflicts. New York: Harper.

Lv, Y. (2014). Cooperative Learning: An Effective Approach to College English Learning. Theory and

Practice in Language Studies, 4(9), 1948-1953.

Magajna, L. et al. (2008). Učne težave v osnovni šoli: koncept dela. Ljubljana: Zavod RS za šolstvo.

Marentič Požarnik, B. (1992). Izkustveno učenje - modna muha, skupek tehnik ali alternativni

model. Sodobna pedagogika, 1-2(43), 1-16.

Marentič Požarnik, B. (200o). Psihologija učenja in pouka. Ljubljana: DZS.

Marentič Požarnik, B., \& Plut Pregelj, L. (2009). Moč učnega pogovora. Ljubljana: DZS.

Marjanovič - Umek, L. et al. (2004). Razvojna psihologija. Ljubljana: Znanstvenoraziskovalni inštitut Filozofske fakultete.

Montasser, M. A. W. M. (2014). The Effectiveness of Using the Cooperative Language Learning Approach to Enhance EFL Writing Skills among Saudi University Students. Journal of Language Teaching and Research, 5(3), 616-625.

Nicolas, J. D., \& Miller, R. B. (1994). Cooperative Learning and Student Motivation. Contemporary Educational Psychology, 19, 161-178.

Novak, M. et al. (2009). Smernice za izobraževanje otrok tujcev v vrtcih in šolah. Ljubljana: Zavod RS za šolstvo. Retrieved 05.03.2014 from http://www.zrss.si/pdf/OEMS_TUJCI\%20-\%20SMERNICE\%20 -\%2ousklajeno\%2ojunij\%2odoc\%2021\%208\%202009.pdf

Papalia, D. E., Olds, S. W., \& Feldman, R. D. (2001). Human Development. New York: McGraw-Hill.

Peklaj, C. et al. (2001). Sodelovalno učenje ali kdaj več glav več ve. Ljubljana: DZS.

Petek, T. (2012). Ozaveščenost o javnem govornem nastopanju - priložnost za profesionalni razvoj 
učitelja. Jezik in slovstvo, 57(3-4), 115-129.

Petek, T. (2013). Vloga in položaj slovenščine v vzgojno-izobraževalnem procesu. Pedagoška obzorja, $28(1), 32-44$.

Plut Pregelj, L. (2012). Poslušanje: način življenja in vir znanja. Ljubljana: DZS.

Potočnik, N. (2010). Učinek udejanja faz v procesu nastajanja neumetnostnih besedil. Doktorska disertacija. Ljubljana: Pedagoška fakulteta.

Program osnovna šola. Slovenščina. Učni načrt (2011). Ljubljana: Ministrstvo RS za šolstvo. Retrieved 05.03.2014 from http://www.mizs.gov.si/fileadmin/mizs.gov.si/pageuploads/podrocje/os/prenovljeni_ UN/UN_slovenscina_OS.pdf

Ross, J., \& Smythe, E. (1995). Differentiating cooperative learning to meet the needs of gifted learners. A case for transformational leadership. Journal for the Education of the Gifted, 19, 63-82.

Sharan, Y. (2010). Cooperative Learning for Academic and Social Gains: valued pedagogy, problematic practice. European Journal of Education, 45(2), 300-313.

Sharan, S., \& Shachar, H. (1988). Language and Learning in the Cooperative Classroom. New York: Springer.

Siltala, R. (2010). Innovativity and cooperative learning in business life and teaching. University of Turku.

Slavin, R. E. (1983). When Does Cooperative Learning Increase Student Achievement? Psychological Bulletin, 94(3), 429-445.

Yazdani Moghaddam, M., \& Fakhraee Faruji, L. (2013). Cooperative Tasks and Lexical Development of EFL Learners. The Electronic Journal for English as a Second Language, 17, 2.

Vodopivec, I., \& Peklaj, C. (2003). Sodelovalno učenje v praksi. Modeli poučevanja in učenja. Ljubljana: Zavod Republike Slovenije za šolstvo.

Žarkovič Adlešič, B. (200o). Delo z razredom. In M. Pušnik, B. Žarkovič Adlešič, \& C. Bizjak, Razrednik v osnovni in srednji šoli (pp. 65-07). Ljubljana: Zavod Republike Slovenije za šolstvo.

\section{Biographical note}

Alenka Rot Vrhovec is Assistant for the didactic of Slovenian language at the Faculty of Education in Ljubljana, preceded by two decades of teaching at primary school. Her research is focused on the field of Slovenian language teaching at primary level, namely literecy, and teaching children whose first language is not Slovenian. She is co-author of textbook materials and e-teaching tools and provider of seminars in Slovenia and abroad. 